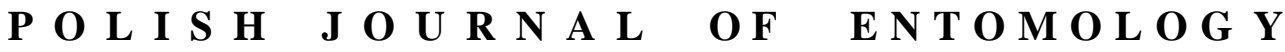

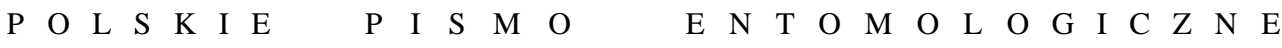

VOL. 83: $269-280$

Lublin

31 December 2014

DOI: $10.2478 /$ pjen-2014-0021

\section{Effect of weather conditions on light-trap catches of Trichoptera in Hungary (Central Europe)}

\author{
LÁSZLÓ NOWINSZKY ${ }^{1}$, OTTÓ KISS ${ }^{2}$, JÁNOS PUSKÁS ${ }^{1}$ \\ ${ }^{1}$ University of West Hungary, Savaria University Centre, Károlyi Gáspár Square 4, \\ H-9700 Szombathely, e-mail: lnowinszky@gmail.com, pjanos@gmail.com \\ ${ }^{2}$ Eszterházy Károly College, Department of Zoology, Eszterházy Square 1, H-3300 Eger, \\ e-mail: otto_kiss@freemail.hu
}

\begin{abstract}
The study deals with the effect of weather conditions on the light trap catch of 2 caddisflies (Trichoptera) species: Hydropsyche bulgaromanorum and Setodes punctatus. We found that the light trap catch of both species increased when the daily maximum temperature, minimum and average values of temperature was higher. The results can be written down with second- or third-degree polynomials. The fluctuation in temperature had no clear influence on the catch. The hydrothermal quotient has a strong influence on the catch of both species. Precipitation has no significant influence on the catch of the tested species.
\end{abstract}

KEY WORDS: caddisflies, light-trap, weather conditions.

\section{INTRODUCTION}

Temperature may have an important influence from the point of view of insects' flying activity. The given temperature requirements of insects can be explained by the fact that their body mass is very small compared to both its surface and the environment. That is why the temperature of their body, instead of being permanent and self-sufficient, follows the changing temperature of the environment. This is because the ratio of the body mass and surface of insects determines the difference between the inner heat content and the incoming or outgoing heat. The heat content of the body is proportional to its mass, while, on the other hand, the heat energy intake or loss is proportional to the size of the surface of 
the body. Therefore an external effect makes its influence felt as against the inner, small heat content of a relatively small mass. The speed as well as the size of the impact brings on the ratio between the mass and surface of the body of the insect (BACSÓ 1964). And so the temperature value always exerts a substantial influence on the life processes of insects. The chemical processes described as metabolism that determine the life functions of insects always follow the temperature changes in the direct surroundings. Naturally, the activity of the organs of locomotion also depends on the temperature of the environment which explains why we can expect a massive light-trap turnout at what is an optimal temperature for the given species (MANNINGER 1948). SOUTHWOOD (1978), on the other hand, is of the view that the flight of insects has a bottom and top temperature threshold typical of each species. The insect flies if the temperature is above the bottom and below the top threshold and becomes inactive when the value is below the bottom or above the top threshold. In his view, other reasons explain the fluctuations in the number of specimens experienced in the interval between the low and high threshold values. However, research in Hungary has proved that in the context of a single species, a significant regression can be established between the temperature values and the number of specimens collected by a light-trap (JÁRFÁs 1979, NOWINSZKY et al. 2003). Polish research has also confirmed that the number of noctuids light-trapped increases with the rise of temperature (BUSZKO \& NOWACKI 1990).

Researchers in many countries of the world have gathered Trichoptera species using light-traps. Examples are the following: SODE \& WiBERG-LARSEN (1993) in Denmark, COLliER et al. (1977) in New Zealand, CRICHTON (1978) in Great Britain, MALICKY (1987) in Austria, ÚJVÁROSI (1999) in Romania, KISS (2004) in Hungary, CZACHOROWSKI \& SERAFIN (2004) in Poland and Belarus, DiCKEN \& BOYACI (2008) in Turkey, Higler et al. (2008) in Netherland, STANIĆ-KoŠTrOMAN et al. (2012) in Bosnia and Herzegovina, RYCHŁA \& BUCZYŃSKA (2013) in Poland, BUCZYŃSKA et al. (2014) in Russia.

Many studies also deal with the effect of weather conditions on light-trap catches of different Trichoptera species.

According to USSEGLIO-Polatera (1987) the wind has a powerful influence on the flight direction of Trichoptera adults which generally fly against the wind. SODE \& WIBERG-LARSEN (1993) contradict this, their results show a lot of Silo pallipes fly downwind. CIUBuC (1989) in Romania studied the effectiveness of light traps for two Trichoptera species as a function of temperature, wind speed, humidity and precipitation.

WARINGER (1991) tested the influence of precipitation, wind speed and night air temperature on light-trap catch of Trichoptera, but only the effect of air temperature was correlated with flight activity.

WARINGER (1991) collected imagos Trichoptera for 1 year (between February 1989 and March 1990) on the coast of Danube, in Lower Austria (Bad Deutsch Altenburg), with 
a Jermy-type light-trap. The influence of precipitation, wind speed and night air temperature (maximum, mean and minimum) on catch success was tested. Only the air temperature was significantly related to flight activity, however, this had a very significant effect $(\mathrm{p}<0.001)$. There was not any catch if the maximum temperature was under $6.8{ }^{\circ} \mathrm{C}$, and the catch was highest on the warmest nights.

KIMURA et al. (2008) found a significant correlation between the daily caddisflies catches and average daily temperature. There were no imagos collected on those days when the average daily air temperature was lower than $10.7^{\circ} \mathrm{C}$.

The study of HIROBAYASHI et al. (2011) indicates that the average temperature in summer, and floods, influenced the seasonal mass of Psychomyia acutipennis ULMER, 1908 imagos.

In an earlier paper (KISS et al. 2011) we examined the relationship between the success of light trapping Ecnomus tenellus Rambur with air temperature measured at $10 \mathrm{pm}$. The results prove, there is an increase in the catch with an increase in air temperature between 11 and $23{ }^{\circ} \mathrm{C}$. This increase can be described with an exponential function between the range of lower and higher temperature threshold. The collection was especially successful above $19^{\circ} \mathrm{C}$. In the same temperature range the number of nights with unsuccessful catch decreased linearly with increasing temperature.

PROMMI et al. (2012) in Thailand found that the air temperature and relative humidity are particularly important, and the higher temperature and low humidity shorten the life of aquatic beetles groups. A microclimate can affect flight activity of aquatic species.

We examined in our present study the influence of weather conditions that affect the light-trap catch in Hungary, near the Tisza River in Szolnok Region. The data of the two Trichoptera species which were caught in largest numbers, were processed.

\section{MATERIAL AND METHODS}

We used Jermy-type light-traps near Szolnok (geographical coordinates: $47^{\circ} 10^{\prime} \mathrm{N}$, $20^{\circ} 11^{\prime}$ E) on coast of the River Tisza (KISS \& ZsUGA, 2012). Light-traps were in operation on all nights between $1^{\text {st }}$ June and $30^{\text {th }}$ September in 2000. In this study, the following species were selected: (1) Hydropsyche bulgaromanorum MALICKY, 1977 (Trichoptera: Hydropsychidae), at 94 nights 22500 individuals; (2) Setodes punctatus FABRICIUS, 1759 (Trichoptera: Leptoceridae), at 86 nights 1848 individuals.

The Jermy-type light-trap has the following characteristics:

The lamp is $200 \mathrm{~cm}$ above the ground; the light source is a 100W normal electric bulb; the metal roof protects the light source and also the captured insects from rain. Chloroform 
was used as the killing agent. The trap was in operation from sunset till sunrise. Determination of trapped insects and data logging took place in the morning.

The weather data, necessary to our investigations, were abstracted from daily weather reports issued by the National Weather Service. We examined the effect of the following weather features: daily maximum and minimum temperatures; daily mean temperature; daily temperature oscillation; hydrothermal quotient (maximum/minimum); maximum wind speed; daily rainfall $(\mathrm{mm})$; occurrence of rain showers and thunderstorms.

We calculated relative catch values from the number of specimens trapped. The relative catch was defined as the quotient of the number of individuals of the species caught during a sampling time unit (1 night) per the average catch (number of individuals of all species) from that trap, relating to the same time unit. For example when the actual catch was equal to the average individual number captured, the relative catch value was 1 (NOWINSZKY 2003).

Data on the weather elements was organized into groups according to the method of STURGES (ODOR \& IGLÓI 1987). The relative catch values of both species were grouped according to the weather elements and then the values were summarized and averaged. Finally we plotted our results.

\section{RESULTS AND DISCUSSION}

Our results are shown in Figures 1-11.

The characteristic curves and associated parameters are indicated in the figures and significance levels are also given.

Our results are usually characterized by a second or third degree polynomial.

We found that the light trap catch of both species increased when the daily maximum temperature, minimum and average values of temperature is higher. The fluctuation in temperature did not affect captures of Hydropsyche bulgaromanorum, but the catch of Setodes punctatus decreased when the temperature change was high.

As an important new result, we found that the hydrothermal quotient had a strong influence on the outcome of collections of both species. The numbers of both species was the highest when the daily maximum and minimum value of the ratio was between 1.2 and 1.8. This means that the catch was largest on those days when the maximum and minimum deviation is moderate.

The effect of maximum wind speed on catching Hydropsyche bulgaromanorum was not conclusive; however Setodes punctatus could be caught in lively winds.

Precipitation had no significant influence on the catch of the tested species. These results are therefore not shown. 


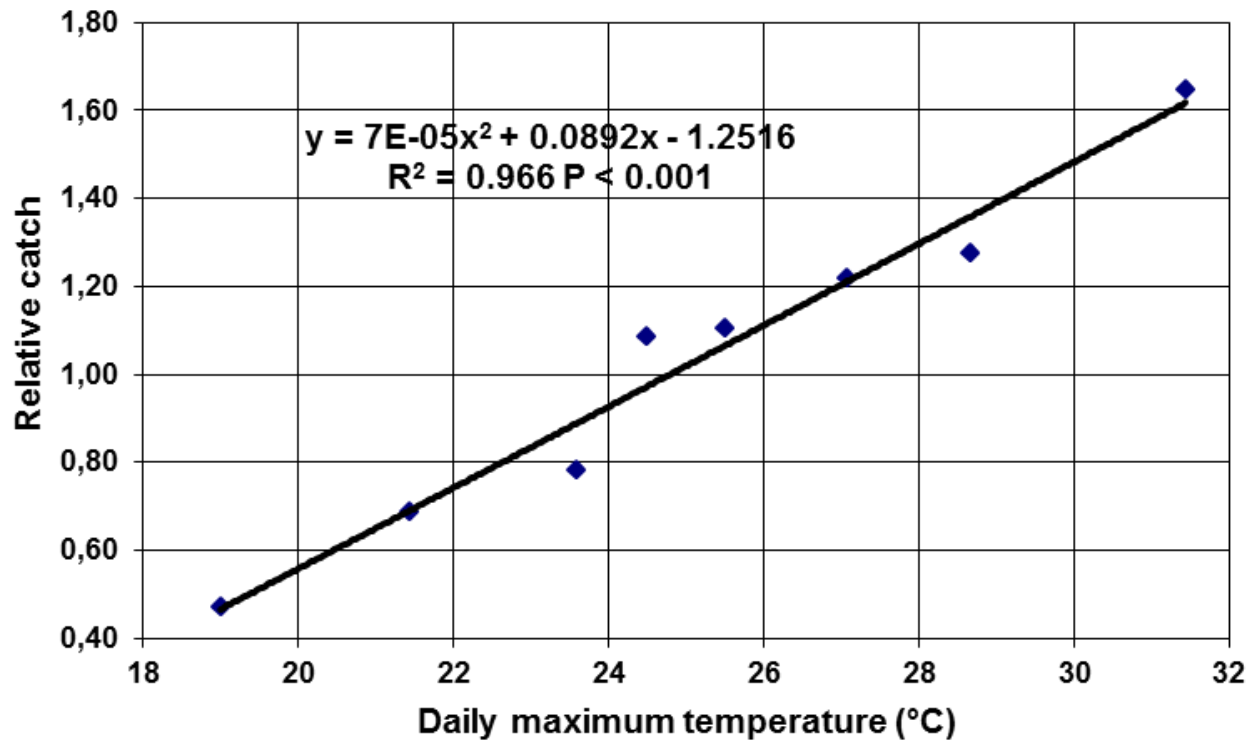

Fig. 1. Light-trap catch of Hydropsyche bulgaromanorum depending on the daily maximum temperature (Szolnok, 2000).

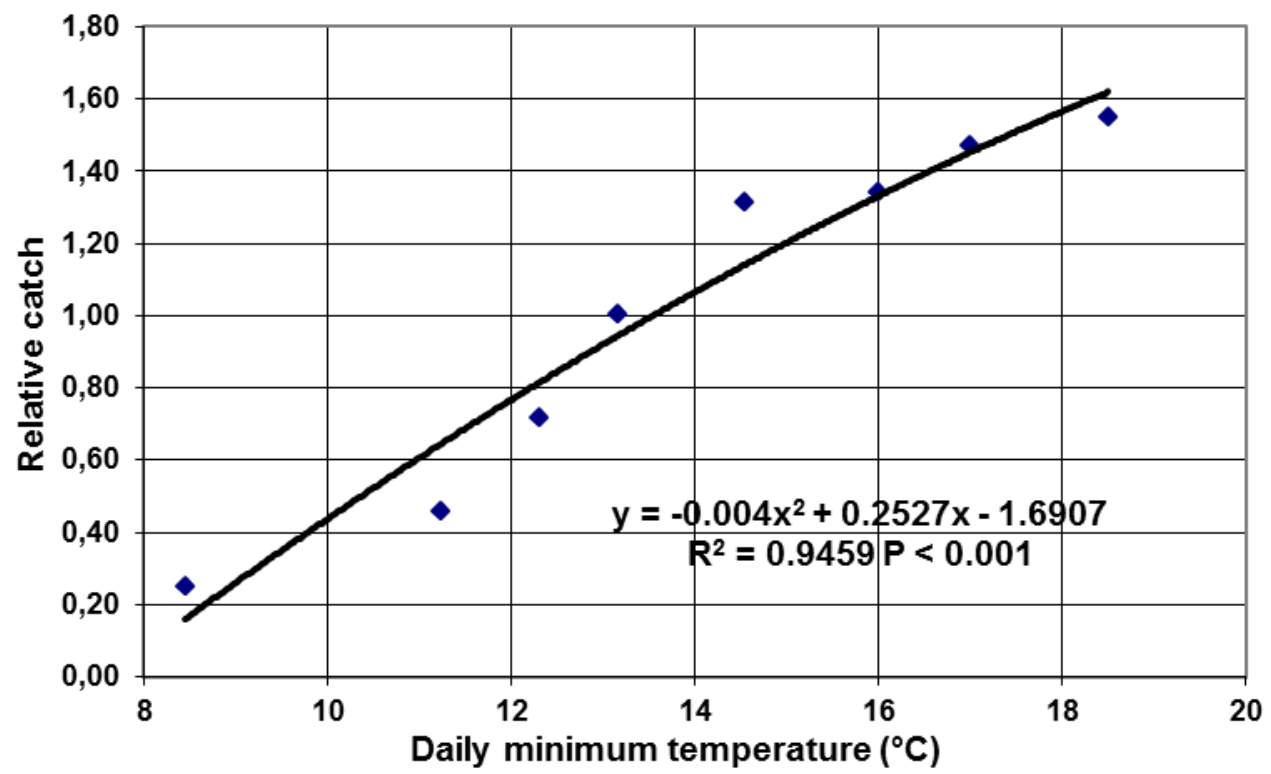

Fig. 2. Light-trap catch of Hydropsyche bulgaromanorum depending on the daily minimum temperature (Szolnok, 2000). 


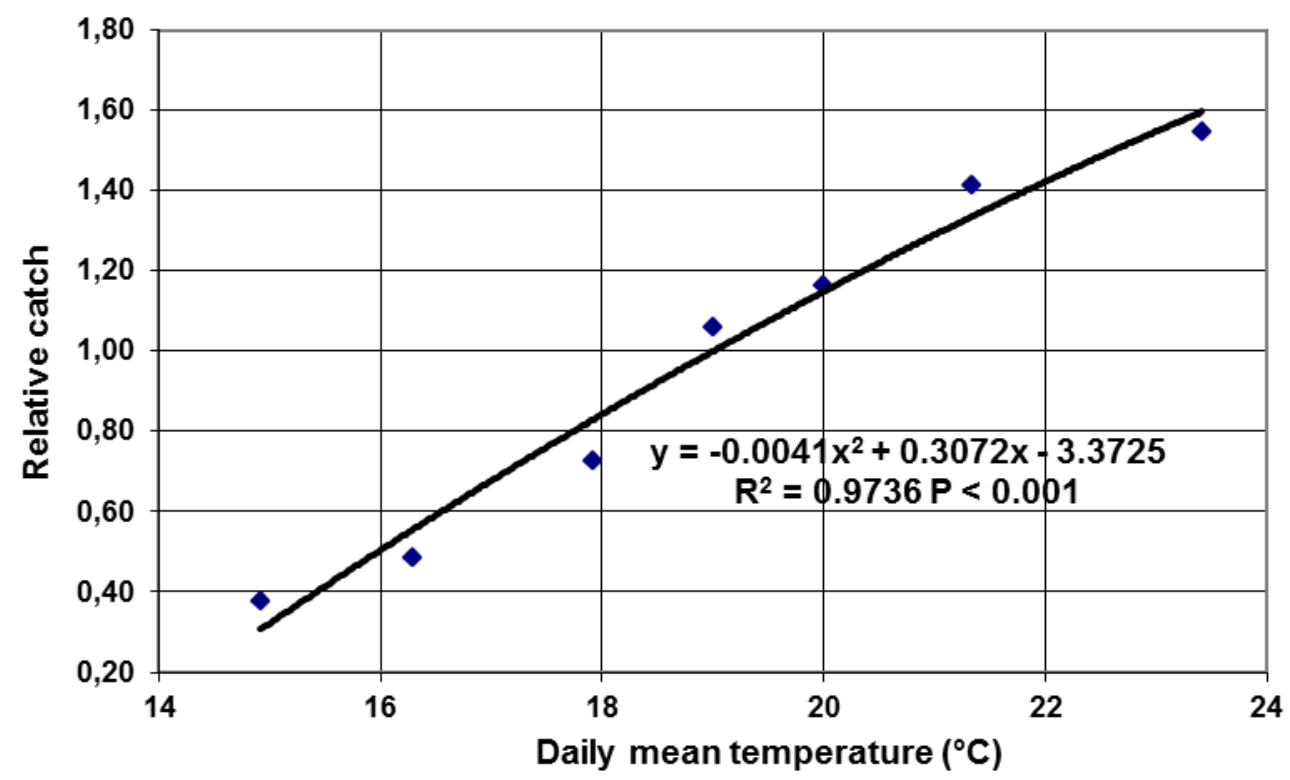

Fig. 3. Light-trap catch of Hydropsyche bulgaromanorum depending on the daily mean temperature (Szolnok, 2000).

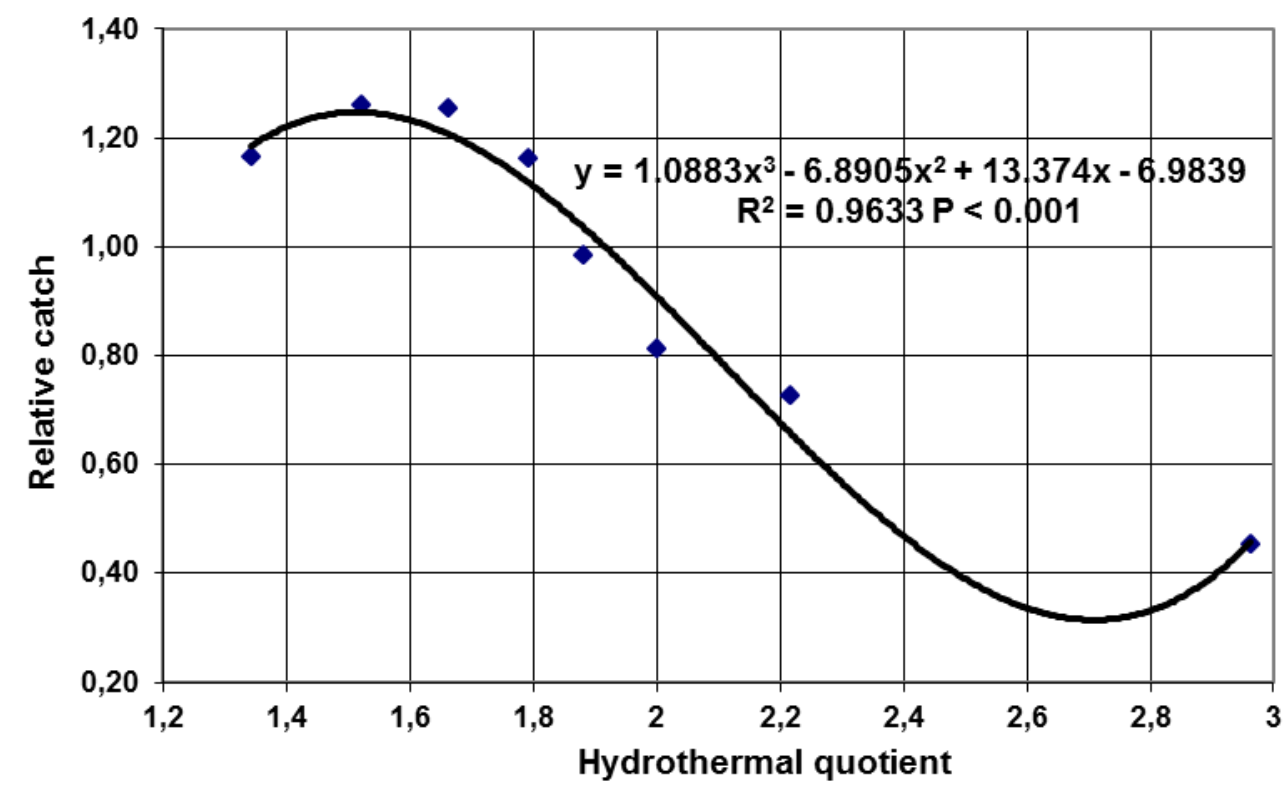

Fig. 4. Light-trap catch of Hydropsyche bulgaromanorum depending on the hydrothermal quotient (Szolnok, 2000). 


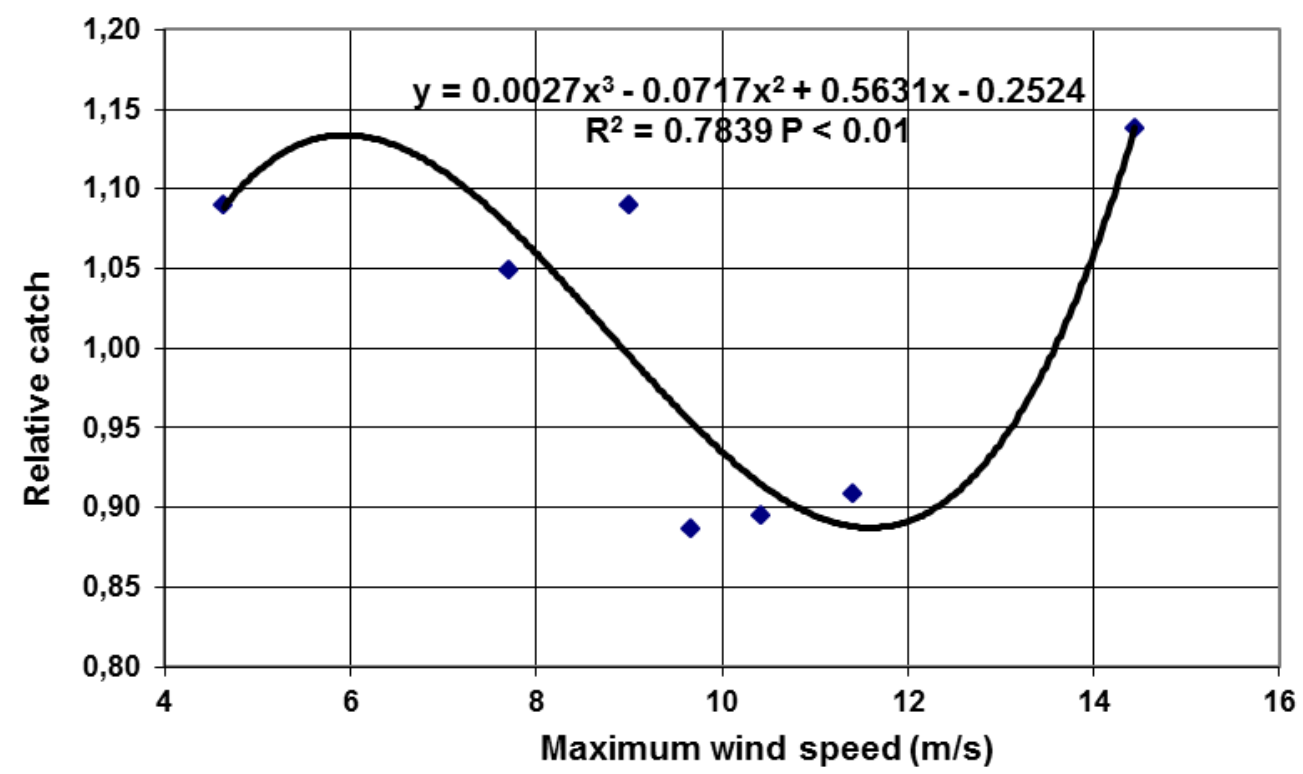

Fig. 5. Light-trap catch of Hydropsyche bulgaromanorum depending on the maximum wind speed (Szolnok, 2000).

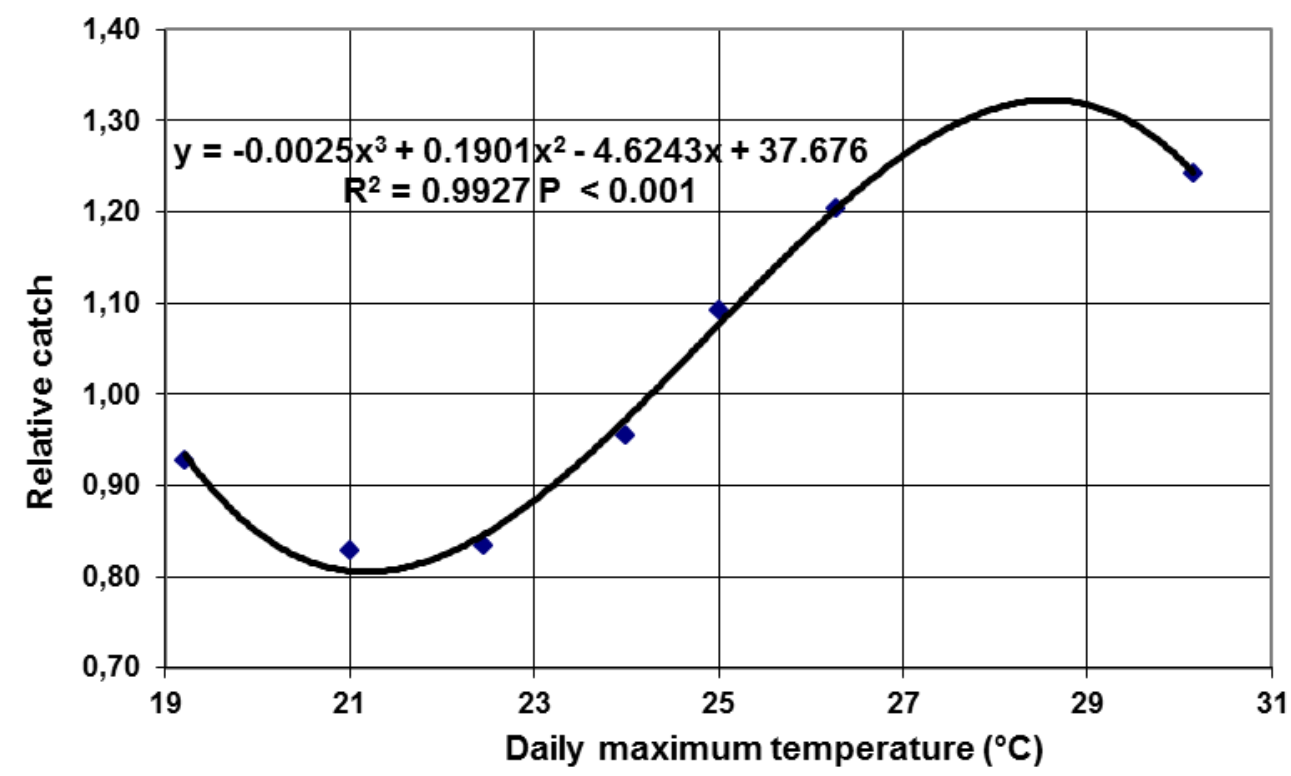

Fig. 6. Light-trap catch of Setodes punctatus depending on the daily maximum temperature (Szolnok, 2000). 


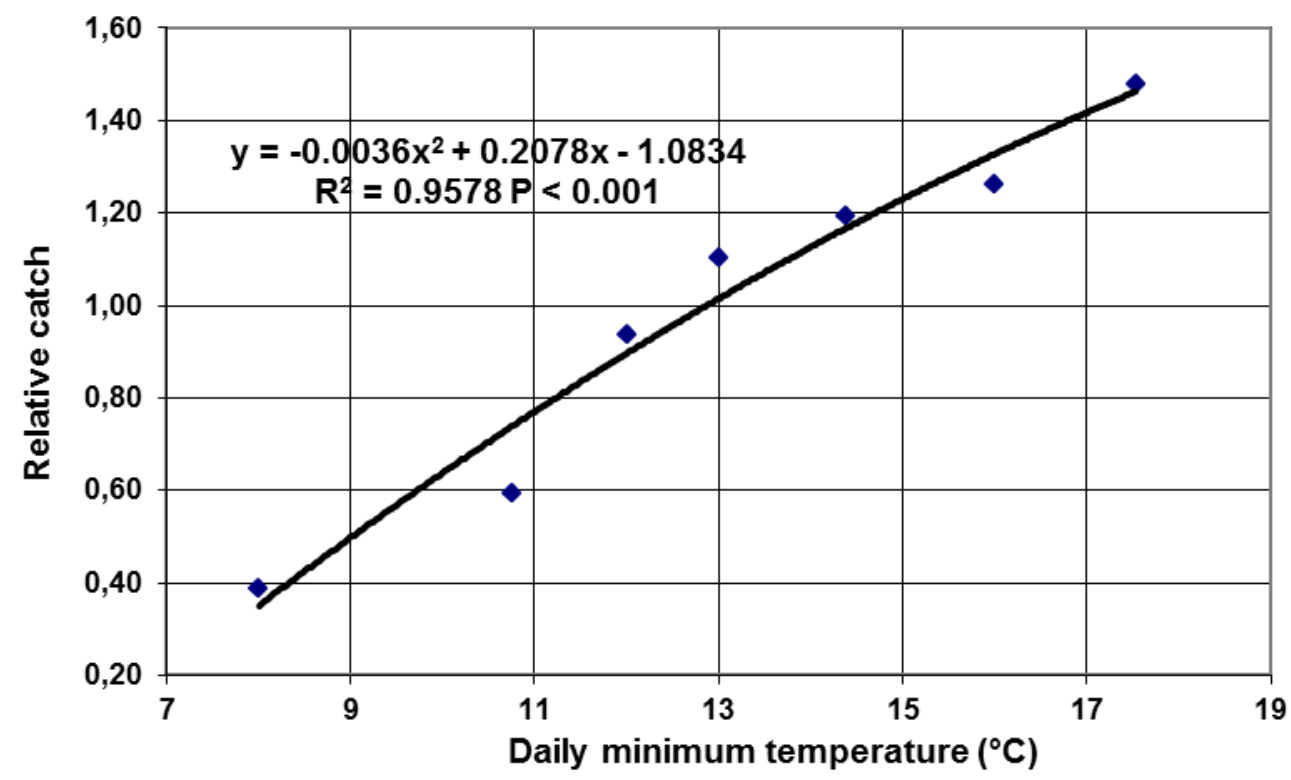

Fig. 7. Light-trap catch of Setodes punctatus depending on the daily minimum temperature (Szolnok, 2000).

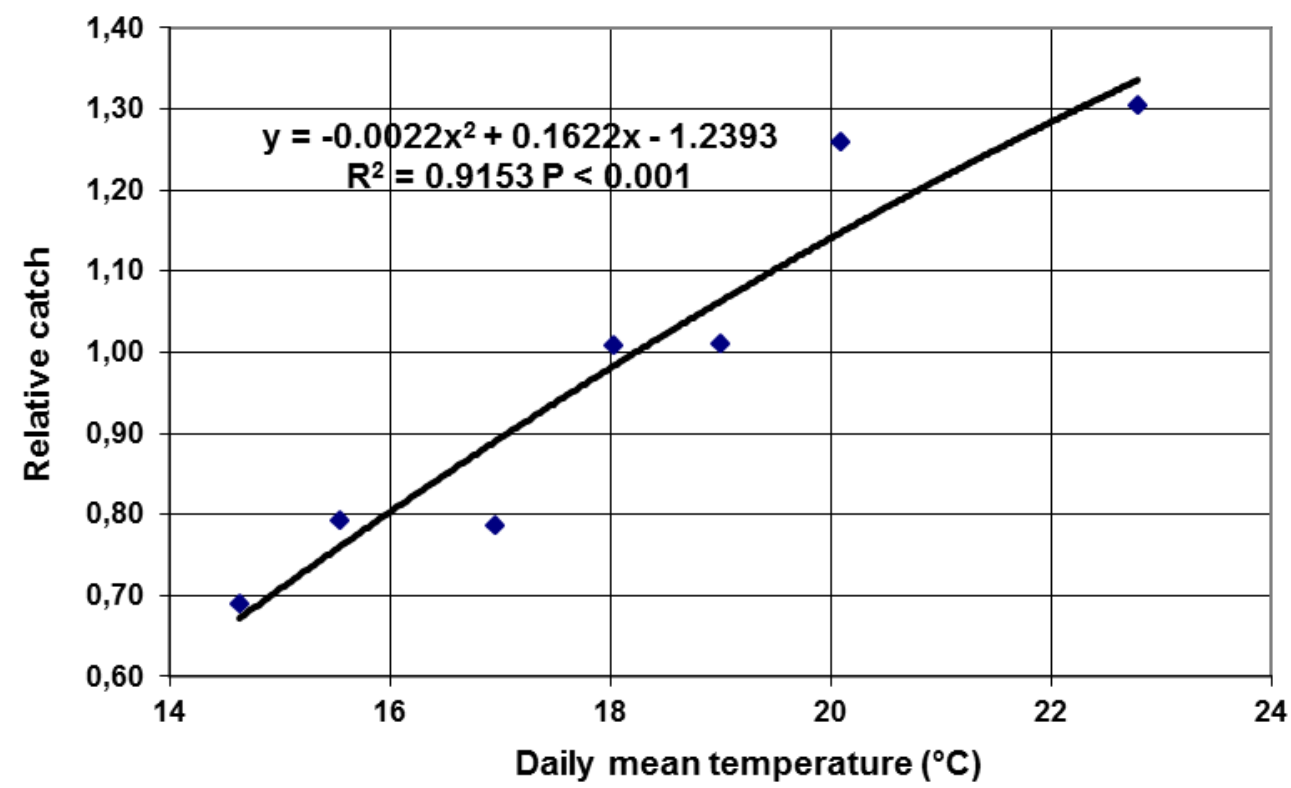

Fig. 8. Light-trap catch of Setodes punctatus depending on the daily mean temperature (Szolnok, 2000). 


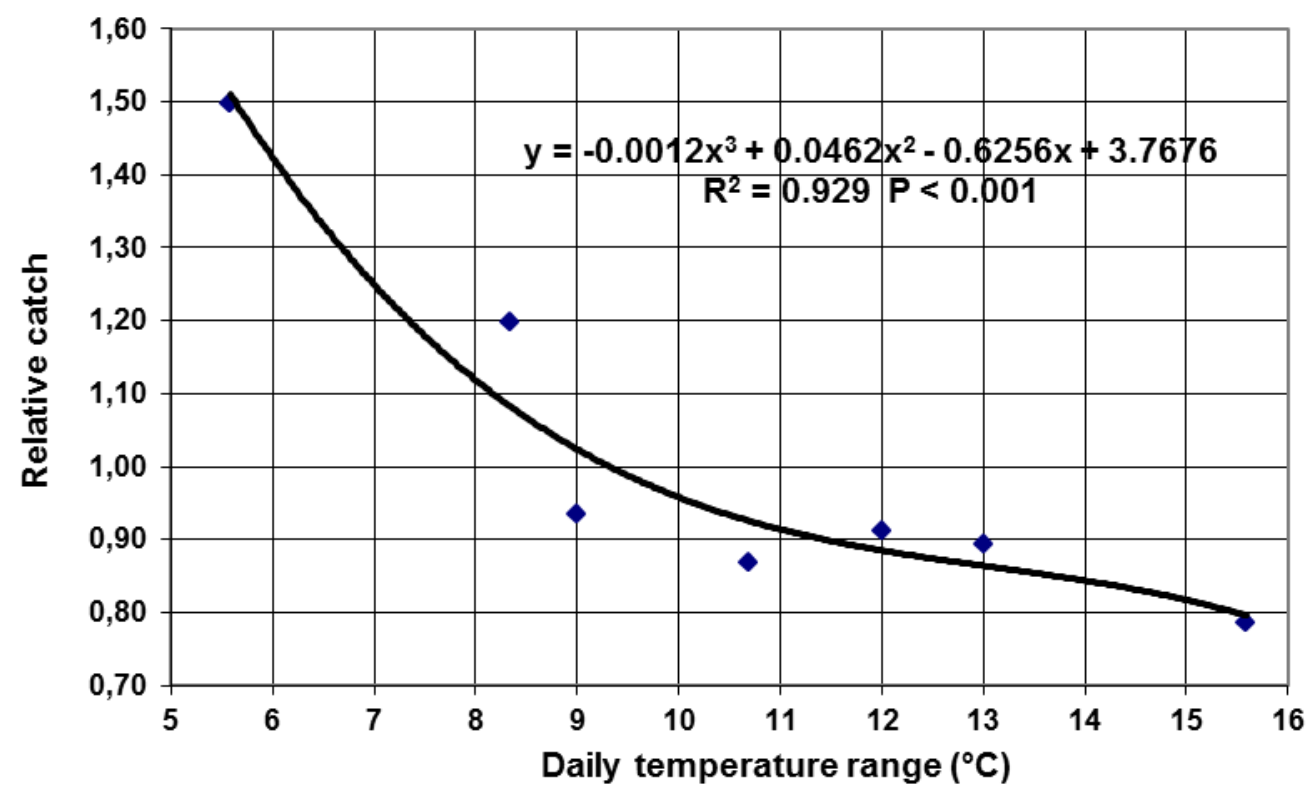

Fig. 9. Light-trap catch of Setodes punctatus depending on the daily temperature range (Szolnok, 2000).

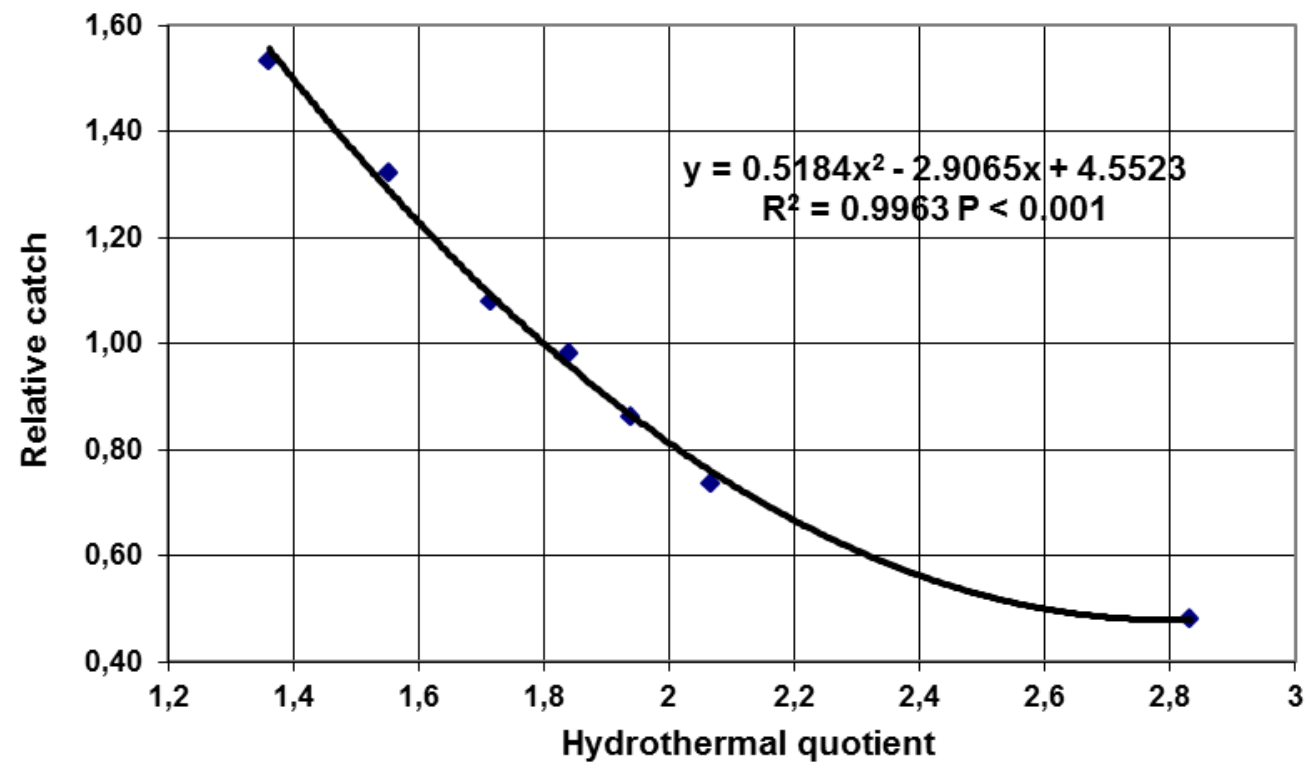

Fig. 10. Light-trap catch of Setodes punctatus depending on the on the hydrothermal quotient (Szolnok, 2000). 


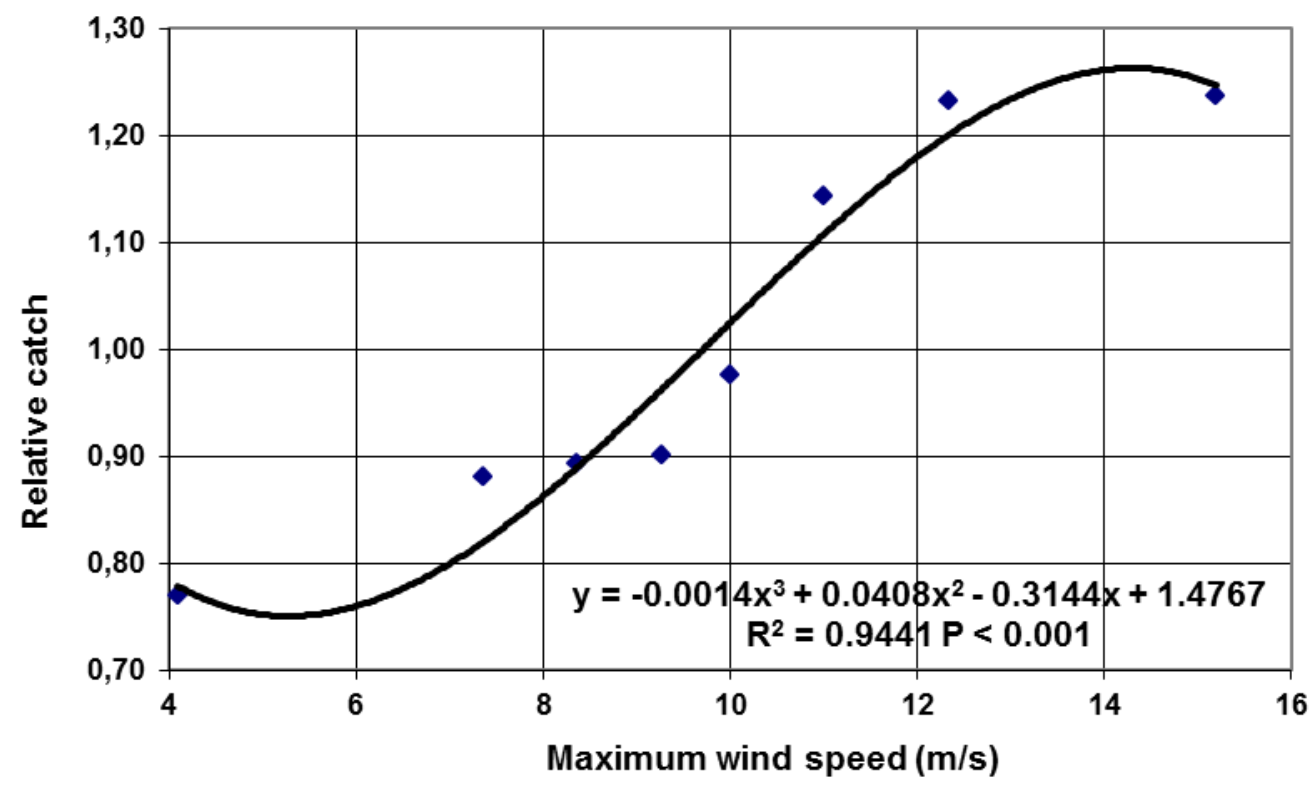

Fig. 11. Light-trap catch of Setodes punctatus depending on the on the maximum wind speed (Szolnok, 2000).

In the future, we plan to publish the results of similar investigation into other species caught at Szolnok with a summary paper to consider all the results.

\section{REFERENCES}

BACSÓ N. 1964. Agrometeorological bases of plant protection. Gödöllő Agrártudományi Egyetem, Gödöllö. (in Hungarian)

BuCZyŃSKA E., ShAPOVAL A., BuCZYŃSKi P. 2014. The northermost European record of Parasetodes respersellus (Trichoptera: Leptoceridae) from the Courish Spit (Russia) with notes on its distribution and imaginal morphology. Turkish Journal of Zoology 38(5): 631-636.

BuszKo J., NowACKI J. 1990. Catch activity of noctuid moths (Lepidoptera, Noctuidae) on light and sugar attractant in relation to the temperature and air humidity. Wiadomości Entomologiczne 9(1-2): 13-20. (in Polish)

Ciubuc C. 1989. Quelques aspects de l'ecologie des populations de Trichopteres recoltes par pieges lumineux en Roumanie. [in:] C. ToMASZEWSKI (ed.). Proceedings of the Sixth International Symposium on Trichoptera. Łódź-Zakopane (Poland), 12-16 September 1989. Adam Mickiewicz University Press, Poznań, 225-231. 
Collier K.J., Smith B.J., BAillie B.R. 1997. Summer light-trap catches of adult Trichoptera in hillcountry catchments of contrasting land use, Waikato, New Zealand. New Zealand Journal of Marine Freshwater Research 31(5): 623-634.

CRICHTON M.I. 1978. Life histories and distribution of British Trichoptera, excluding Limnephilidae and Hydroptilidae, based on the Rothamsted Insect Survey. Holarctic Ecology 1(1): 31-45.

CZAChOROWSKI S., SERAFin E. 2004. The distribution and ecology of Hydropsyche bulgaromanorum and Hydropsyche contubernalis (Trichoptra: Hydropsychidae) in Poland and Belarus. Lautebornia 50: $85-98$.

DiCKEN G., BOYACI Y.Ö. 2008. Light trapping of caddisflies (Insecta: Trichoptera) from Eğirdir Lake in the southern Turkey. Journal of Fisheries Sciences 2(4): 653-661.

Higler B., SPIJKers H., Wielink P. 2008. A two-year survey of Trichoptera caught on light in the Kaaistoep (The Netherlands). Entomologische Berichten 68(5): 175-181.

Hirabayashi K., Kimura G., Inoue E. 2011. Adult caddisflies (Trichoptera) attracted to artificial lights in the middle reaches of the Shinano River from 2005 to 2007. Zoosymposia 5: 143-146.

JÁRFÁS J. 1979. Forecasting of harmful moths by light-traps. PhD Thesis, Univeristy of Agriculture, Kecskemét. (in Hungarian)

Kimura G., InOUe E., HiRABAyASHI K. 2008. Seasonal abundance of adult caddisfly (Trichoptera) in the middle reaches of the Shinano River in Central Japan. [in:] W.H. Robinson, D. BAJOMI (eds). Proceedings of the Sixth International Conference on Urban Pests, Europa Congress Center, Hungary, 13-16 July 2008. OOK-Press, Veszprém, 258-266.

KISS O. 2004. The weather quality state in the middle section of River Tisza, Hungary. Braueria 31: $13-19$.

Kiss O., ZsugA K. 2012. Trichoptera collected by light trapping from the Hungarian section of the River Tisza. Braueria 39: 25-41.

Kiss O., Nowinszky L., Szentkirályi F., Puskás J., Barabás S. 2011. The influence of air temperature on the success of light trapping in the case of Ecnomus tenellus RAMBUR (Trichoptera: Ecnomidae) living in water habitats. Hidrológiai Közlöny 91(6): 119-120. (in Hungarian)

MALICKY H. 1987. Anflugdistanz und Fallenfangbarkeit bei Köcherfliegen (Trichopera) bei Lichtfallen. Jahresbericht der Biologischen Station Lunz 10: 140-157.

MANNINGER G.A. 1948. Connection between the climate, weather and the harmful animals. [in:] A. RÉTHLy, L. AujesZKY (eds). Agrometeorology. Országos Meteorológiai és Földmágnességi Intézet, Budapest. (in Hungarian)

NowinsZKY L. (ed.) 2003. The Handbook of Light Trapping. Savaria University Press, Szombathely.

NowinsZKY L., EKK I., PuSKÁs J. 2003. Chapter 7.2.19. Weather elements. [in:] L. NowinSZKY (ed.). The Handbook of Light Trapping. Savaria University Press, Szombathely, 161-167.

OdOR P., IGLói L. 1987. An introduction to the sport's biometry. ÁISH Tudományos Tanácsának Kiadása, Budapest. (in Hungarian) 
RychŁA A., BuczyŃSKa E. 2013. Species richness and diversity of caddisflies (Trichoptera) in a selected area in mid-western Poland (Lubuskia Province). Annales Universitatis Mariae CurieSkłodowska (sec. C) 68(1): 55-73.

Sode A., Wiberg-Larsen P. 1993. Dispersal of adult Trichoptera at a Danish forest brook. Freshwater Biology 30(3): 439-446.

SouthwOOD T.R.E. 1978. Ecological methods with particular reference to the study of insect populations (Second ed.). Chapman and Hall, London.

Stanić-Koštroman S., Mladen Kučinić M., Kolobara A., Dragan Škobić D., Knezović L., DURBEŠIĆ P. 2012. Light-trapped caddisflies (Insecta: Trichoptera) as indicators of the ecological integrity of the Lištica River, Bosnia and Herzegovina. Entomologia Croatica 16(1-4): 21-36.

Prommi T., SeEtapan K., Thamsenanupap P. 2012. Diversity and seasonality of caddisflies (Insecta: Trichoptera) at Champathong waterfall, northern Thailand. SDU Research Journal 5(2): 125-138.

ÚJVÁROSI L. 1998. Four Trichoptera species new in Romanian fauna. Entomolologia Romanica 3: 73-78.

UsSeglio-Polatera P. 1987. The comparison of light trap and sticky trap catches of adult Trichoptera (Lyon, France). [in:] M. Bouchard, H. TACHET (eds). Proceedings of the Fifth International Symposium on Trichoptera, Lyon, 21-26 July 1986. Series Entomologica 39: $217-222$.

WARINGER J.A. 1991. Phenology and the influence of meteorological parameters on the catching success of light-trapping for Trichoptera. Freshwater Biology 25(2): 307-319.

Received: 7 May 2014

Accepted: 23 September 2014 